\title{
Giant Spiradenoma Mimicking Soft Tissue Sarcoma in Upper Extremity
}

\section{Üst Ekstremitede Sarkom Görünümünü Taklit Eden Dev Spiradenom}

\author{
Galip Gencay Üstün ${ }^{1}$, Melike Oruc ${ }^{1}$, Oğuz Atan ${ }^{1}$, Muzaffer Çaydere ${ }^{2}$, Koray Gürsoy ${ }^{1}$, Uğur \\ Koçer $^{1}$ \\ ${ }^{1}$ Ankara Eğitim ve Araştırma Hastanesi Plastik Rekonstrüktif ve Estetik Cerrahi Kliniği \\ ${ }^{2}$ Ankara Eğitim ve Araştırma Hastanesi Patoloji Kliniği
}

Dergiye Ulaşma Tarihi: 28.11.2018 Dergiye Kabul Tarihi: 06.02.2019 Doi: 10.5505/aot.2019.49469

\section{ÖZET}

Ekrin spiradenoma ter bezlerinden köken alan benign bir yumuşak doku tümörüdür. Ekstremitede oldukça nadir görülmektedir. Yayında sol proksimal ön kol bölgesinde dev kitle ile başvuran bir vakanın olgu sunumu yapılmıştır. İnsizyonel biyopsi esnasında ciddi kanaması olan ve biyopsi sonucu tanı konulamayan hastaya, $2 \mathrm{~cm}$ sağlam cerrahi sınırla eksizyon ve frozen inceleme planlandı. Hastaya nihai inceleme sonucunda ekrin spiradenom tanısı kondu. Ekrin spiradenom benign kabul edilmesine rağmen, üst ektremite kitlelerinde bu olası ve oldukça nadir tanının varlığından haberdar olmak hastaya ve cerraha zaman kazandırmaktadır. Klinik deneyimimize göre, insizyonel biyopsinin yetersiz olması durumunda, eksizyonel biyopsi ve eş zamanlı frozen inceleme tedavi şemasını oluşturmaktadır. İncelemede olası malign transformasyonun akılda tutulması gerekmektedir.

Anahtar Kelimeler: Ekrin spiradenom, üst ekstremite, sarkom, dev, tümör, frozen inceleme

\begin{abstract}
Eccrine spiradenoma is a benign soft tissue tumor arising from sweat glands. Their occurence in extremities is quite rare. Patient presented with a mass lesion is his left proximal forearm. Significant bleeding from the mass occured in incisional biopsy and results were inconclusive so excision of the mass with $2 \mathrm{~cm}$ borders and frozen sampling was planned. Patient was diagnosed with an eccrine spiradenoma. Even though eccrine spiradenoma is a benign condition, awareness of the entity is beneficial and time saving during differentials. According to our experience when incisional biopsy is inconclusive, preparation for total excision and frozen sectioning is the standard of care. Malignant transition must be kept in mind during pathological examination.
\end{abstract}

Keywords: Eccrine spiradenoma, upper extremity, sarcoma, giant, tumor, frozen sectioning

\section{INTRODUCTION}

Eccrine spiradenoma is a soft tissue tumor arising from sweat glands. Most of the cases are benign, however malignant cases have ben reported (1). They frequently occur in the trunk and head (2) and occurence in extremities is quite rare. May mimic benign conditions such as lipoma, ganglion cysts, giant cell tumor of the tendon sheath or malignant conditions such as soft tissue sarcoma when occur in extremities (3). Eccrine spiradenoma is a rare diagnosis but malignant variant of spiradenoma occurs much more infrequent (4).
Patient presented with a giant mass turned out to be a spiradenoma is presented under his informed consent.

\section{CASE PRESENTATION}

Fifty-nine-year-old male patient presented with a $10 \times 10 \mathrm{~cm}$ mass lesion in his left proximal forearm that has been present for 7 years(Figure 1). Personal history reveals no systemic disease but hypertension under control. Magnetic resonance imaging (MRI) revealed $103 \times 72 \times 106 \mathrm{~mm}$ mass over muscle fascia(Figure 2). Two additional smaller 
masses $(41 \times 25 \mathrm{~mm}$ vs. $23 \times 7 \mathrm{~mm})$ were also reported on MRI. Significant bleeding from the mass occured during incisional biopsy and results were inconclusive. Based on MRI findings, excision of the mass with $2 \mathrm{~cm}$ borders and frozen sampling was planned. Specimen was examined with frozen sectioning (Figure 3). After exclusion of malignancy in frozen sampling, defect was

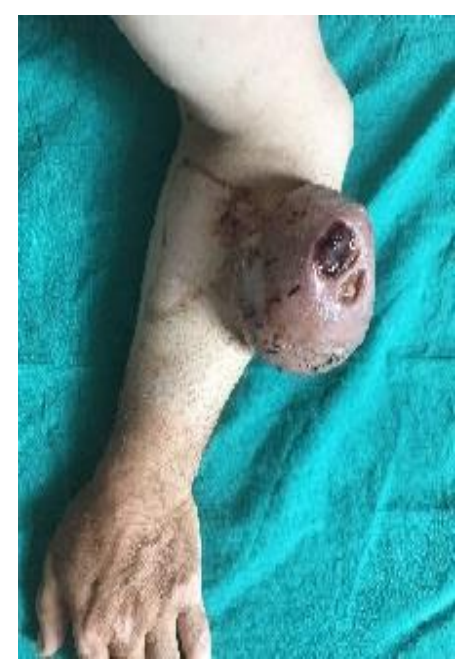

Figure 1 Preoperative view of tumor.

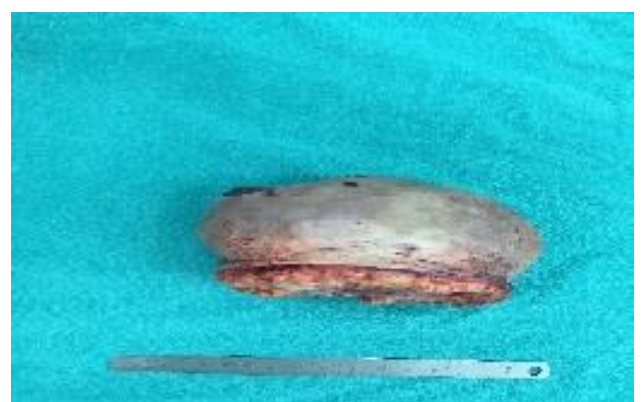

Figure 3 Gross anatomy of biopsy specimen. reconstructed using full thickness skin graft without additional excision (Figure 4 and 5). Definitive pathological examination revealed basophilic nodules in the dermis unattached to epidermis and trabecular arrangement of cells. Patient was diagnosed with an eccrine spiradenoma and healed successfully without any wound complications (Figure 6).

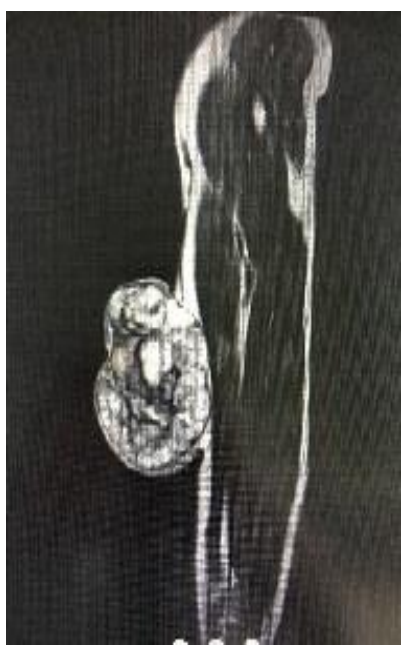

Figure 2 MRI view, please note cross sectional appearance and size of the tumor relative to the forearm.

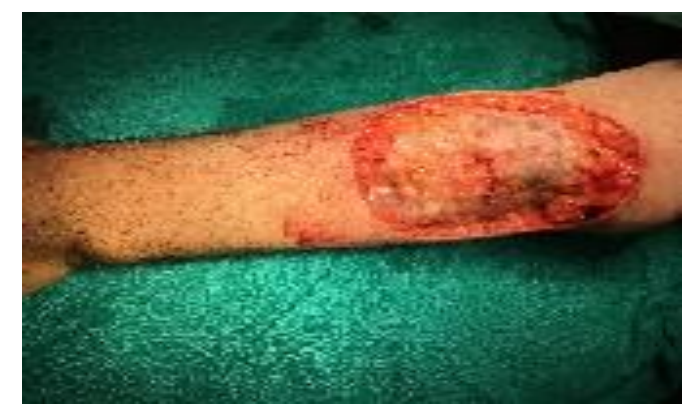

Figure 4 Defect after excision. 


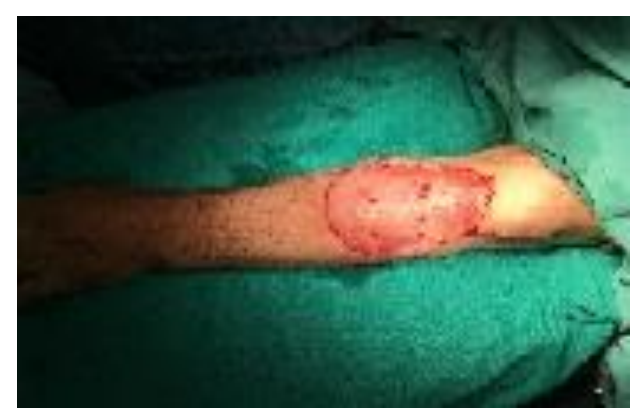

Figure 5 Reconstruction with full thickness skin graft.

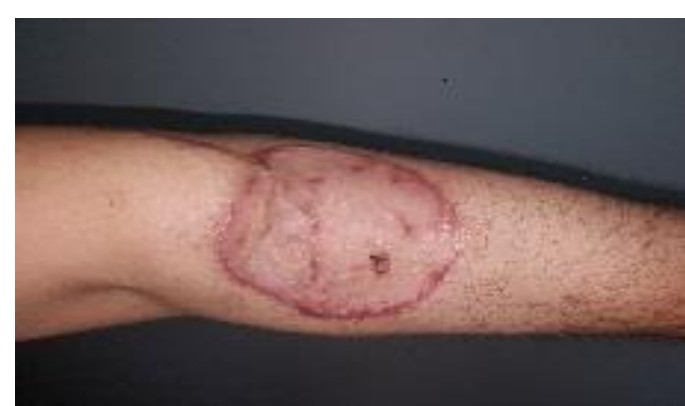

Figure 6 Three-months postoperative vie

\section{DISCUSSION}

For hand surgeon facing an upper extremity tumor, first step is evaluating malignancy potential. Even though eccrine spiradenoma is a benign condition, awareness of the entity is beneficial during differentials. Medical history surely gives an idea to the surgeon about benign/malignant behaviour. As in this case, spiradenoma cases usually have relatively long follow-up periods before consultation.

MRI is helpful during interpreting soft tissue extension. Next step is incisional biopsy, but as in this case, inconclusive biopsy results were presented in the literature (3). When incisional biopsy is inconclusive, preparation for total excision and frozen sectioning are the standard of care.

Eccrine spiradenoma is a benign condition, however, malignant transformation has been reported and should be kept in mind during pathological examination (5). Without findings of malignancy, simple excision with clear margins is enough.

Eccrine spiradenoma is a rare, benign condition that should be kept in mind by hand surgeon facing soft tissue tumors.

\section{Conflict of interest Statement}

The authors declare there are no conflicts of interest-financial or otherwise-related to the products, devices, and drugs mentioned in this manuscript. In addition, this study did not receive any form of funding. Informed consent has been taken from the patient prior to publication.

\section{REFERENCES}

1. Yaremchuk MJ, Elias LS, Graham RR, Wilgis EF. Sweat gland carcinoma of the hand: two cases of malignant eccrine spiradenoma. J Hand Surg Am. 1984;9(6):910-4.

2. Al-Qattan MM. Eccrine spiradenoma of the hand clinically mimicking a lipoma. J Hand Surg Br. 1996;21(4):551-2.

3. Siegel HJ, Said-Al-Naief N, Long J, Lopez-Ben RR, Klein M. Giant eccrine spiradenoma of the hand. Am J Orthop (Belle Mead NJ). 2008:37(8):E141-3.

4. Dhua S, Sekhar DR. A rare case of eccrine spiradenoma-treatment and management. Eur $\mathrm{J}$ Plast Surg. 2016;39:143-6.

5. Dabska M. Malignant transformation of eccrine spiradenoma. Pol Med J. 1972;11(2):388-96. 